\title{
Comparison of Hexavalent Chromium Leaching Levels of Zeolite- and Slag-based Concretes
}

\author{
Jozef Oravec, Adriana Eštoková \\ Technical University of Košice, Slovakia \\ Faculty of Civil Engineering, Institute of Environmental Engineering \\ e-mail: jozef.oravec@tuke.sk, adriana.estokova@tuke.sk
}

\begin{abstract}
In this experiment, the reference concrete samples containing Portland cement as binder and the concrete samples with the addition of ground granulated blast furnace slag $(85 \%$ and $95 \%$, respectively as replacement of Portland cement) and other samples containing ground zeolite $(8 \%$ and $13 \%$, respectively as replacement of Portland cement) were analyzed regarding the leachability of chromium. The prepared concrete samples were subjected to long-term leaching test for 300 days in three different leaching agents (distilled water, rainwater and Britton-Robinson buffer). Subsequently, the concentration of hexavalent chromium in the various leachates spectrophotometrically was measured. The leaching parameters as values of the $\mathrm{pH}$ and the conductivity were also studied. This experiment clearly shows the need for the regulation and control of the waste addition to the construction materials and the need for long-term study in relation to the leaching of heavy metals into the environment.
\end{abstract}

Key words: hexavalent chromium, leaching, zeolite, slag, concrete

\section{Introduction}

With increasing contamination of the environment, the problem of heavy metal immobilization becomes very significant. New technologies will be developed only when heavy-metal-containing by-products can be sufficiently and safely removed. In many research centers, the studies are being carried out to solve this problem. One of possibilities is to incorporate these by-products to construction materials. Although stabilization of wastes is a confirmed technology, little is still known about the mechanisms involved with the leaching of contaminants from the stabilized waste [1].

One of the industrial by-products is granulated blast furnace slag, which after adjustment can be used to replace a part of Portland cement in concrete structures [2]. The granulated blast furnace slag contains a certain amount of heavy metals that are hazardous for the environment. After incorporation into construction materials the amount of leachable heavy metals is rapidly reduced, but on the other hand, is higher than in the case of concrete without slag [3]. 
Other possibility of Portland cement replacement is addition of Puzzolans, which are materials that predominantly consist of reactive $\mathrm{SiO}_{2}$ and $\mathrm{Al}_{2} \mathrm{O}_{3}$ and are able to combine with portlandite $\left(\mathrm{Ca}(\mathrm{OH})_{2}\right)$, a by-product of cement hydration to form further gel products. Therefore, they have been widely used as an additive in cement, in which portlandite is a major hydration product. Their widespread use can be explained by their beneficial effect on the properties of concrete leading to technical, economic and ecological advantages [4]. It is widely accepted that puzzolans can increase the durability of concrete composites, reduce the heat of hydration, increase the resistance to sulfate attack and reduce the energy cost per cement unit. One of the most widely used types of puzzolans is a natural zeolite [5].

There is a need to study whether the incorporation of alternative materials in the production of cement is liable to increase the quantity of heavy metals [6]. The term heavy metal has been used as a general term for those metals and semimetals with potential human or environmental toxicity. One of the most harmful forms of heavy metals is hexavalent chromium. Groundwater is the most threatened by leaching of hexavalent chromium into the environment [7].

The paper presents a comparative study of the chromium leachability from concrete samples containing an addition of ground blast furnace slag and ground zeolite. The hexavalent chromium leaching of waste-based concretes is compared to the reference Portland cement based concrete samples as well.

\section{Material and methods}

To study the leachability of heavy metals from the cement composites, the concrete samples without any additives as well as the concrete containing $85 \%$ and $95 \%$, respectively of a special additive based on slag as a replacement of Portland cement and concrete samples containing $8 \%$ and $13 \%$, respectively of a zeolite as a replacement of Portland cement were prepared (see Table 1). For this experiment Portland cement CEM I $42.5 \mathrm{~N}$ (Povazska cementaren, Ladce, Slovakia); special additive based on slag (Povazska cementaren, Ladce, Slovakia); natural zeolite (Nizny Hrabovec, Slovakia) and aggregates of fraction 0/4mm, 4/8mm, 8/16mm from local sources (Vychodoslovenske stavebne hmoty, Geca, Slovakia) have been used.

Table 1: Mixtures of concrete samples

\begin{tabular}{|c|c|c|c|c|c|}
\hline \multicolumn{2}{|c|}{ Samples } & Cement & Additive & Water & Aggregates \\
\hline Reference & $\mathrm{R}-0 \%$ of additive & 360 & 0 & \multirow{5}{*}{162} & Fractions \\
\hline \multirow[t]{2}{*}{ Zeolite-based } & Z8 - 8\% of zeolite & 331 & 29 & & 0/4mm: 825 \\
\hline & Z13 $-13 \%$ of zeolite & 313 & 47 & & 4/8mm: 235 \\
\hline \multirow[t]{2}{*}{ Slag-based } & S85 - 85\% of slag & 54 & 306 & & 8/16mm: 740 \\
\hline & S95 - 95\% of slag & 18 & 342 & & \\
\hline
\end{tabular}

The concrete samples prepared by standard procedure were cured in water during 28 days, then were cut into smaller specimens with dimensions of $50 \times 50 \times 15 \mathrm{~mm}^{3}$, dried and weighted to the constant weight. Consequently, the concrete samples of various composition as mentioned in Table 1, were placed into three various leaching agents: distilled water (DW) 
with a $\mathrm{pH}$ value of 6.54 and conductivity value of $1.30 \mu \mathrm{S} / \mathrm{cm}$; rain water (RW) with a $\mathrm{pH}$ value of 6.24 and conductivity value of $11.27 \mu \mathrm{S} / \mathrm{cm}$; and Britton-Robinson buffer (BRB) with a $\mathrm{pH}$ value of 2.01 and conductivity value of $3930 \mu \mathrm{S} / \mathrm{cm}$ to long-term tank test leaching. According to the basic characterization tank test reported in CEN/TR 16142, the concrete samples were placed into tanks filled by particular leaching agent so that the specimens were immersed at least $2 \mathrm{~cm}$ to ensure the permanent contact with liquid leaching agent. The leaching of the tested concrete samples proceeded over a period 300 days under laboratory temperature of $20^{\circ} \mathrm{C}$.

Britton-Robinson buffer consisted of a mixture of boric acid $\left(\mathrm{H}_{3} \mathrm{BO}_{3}, 0.04 \mathrm{~mol} / \mathrm{dm}^{3}\right)$, phosphoric acid $\left(\mathrm{H}_{3} \mathrm{PO}_{4}, 0.04 \mathrm{~mol} / \mathrm{dm}^{3}\right)$ and acetic acid $\left(\mathrm{CH}_{3} \mathrm{COOH}, 0.04 \mathrm{~mol} / \mathrm{dm}^{3}\right)$. The original $\mathrm{pH}$ of Britton-Robinson buffer was measured as 2.01. The concentrations of hexavalent chromium in leachates were measured by using spectrophotometer DR 2800 (Hach Lange, Germany). Chromium (VI) content was analyzed spectrophotometrically, as a red-violet complex of chromium formed with 1,5-diphenylcarbohydrazide $\left(1_{\max }=545 \mathrm{~nm}\right.$ at $10 \mathrm{ml}$ cell).

Conductivity and $\mathrm{pH}$ of leaching agent were measured at the beginning and after 300 days of the experiment by using Multimeter X-matePro MX300 (Mettler Toledo) and pH meter FG2 - FiveGo ${ }^{\mathrm{TM}}$ (Mettler Toledo).

\section{Results and discussion}

The $\mathrm{pH}$ of leachates of all samples has been moved from acidic to alkali region due to concretes leaching (Table 2).

Table 2: Changes in $\mathrm{pH}$ and conductivity of leachates due to concretes leaching

\begin{tabular}{|c|c|c|c|c|c|c|c|}
\hline \multirow[b]{2}{*}{ Sample } & \multirow[b]{2}{*}{$\begin{array}{l}\text { Leaching } \\
\text { agent }\end{array}$} & \multicolumn{4}{|c|}{ pH } & \multicolumn{2}{|c|}{ Conductivity } \\
\hline & & Initial & Final & $\begin{array}{l}\text { Absolute } \\
\text { change }\end{array}$ & $\begin{array}{c}\text { Relative } \\
\text { Change } \\
\text { (Final/Initial) }\end{array}$ & $\begin{array}{c}\text { Initial } \\
{[\mu \mathrm{SS} / \mathrm{cm}]}\end{array}$ & $\begin{array}{c}\text { Final } \\
\mu \mathrm{S} / \mathrm{cm}]\end{array}$ \\
\hline $\mathrm{R}$ & \multirow{5}{*}{$\begin{array}{l}\text { Distilled } \\
\text { water }\end{array}$} & \multirow{5}{*}{6.54} & 8.77 & 2.23 & 1.34 & \multirow{5}{*}{1.3} & 532 \\
\hline Z8 & & & 8.66 & 2.12 & 1.32 & & 400 \\
\hline Z13 & & & 8.48 & 2.34 & 1.29 & & 399 \\
\hline S85 & & & 7.91 & 1.37 & 1.21 & & 551 \\
\hline S95 & & & 7.83 & 1.29 & 1.20 & & 531 \\
\hline $\mathrm{R}$ & \multirow{5}{*}{ Rain water } & \multirow{5}{*}{6.24} & 8.87 & 2.63 & 1.42 & \multirow{5}{*}{11.3} & 459 \\
\hline $\mathrm{Z} 8$ & & & 8.76 & 2.52 & 1.40 & & 438 \\
\hline Z13 & & & 8.56 & 2.32 & 1.37 & & 426 \\
\hline S85 & & & 8.44 & 2.20 & 1.35 & & 458 \\
\hline S95 & & & 8.37 & 2.13 & 1.34 & & 496 \\
\hline $\mathrm{R}$ & \multirow{5}{*}{$\begin{array}{l}\text { Britton- } \\
\text { Robinson } \\
\text { buffer }\end{array}$} & \multirow{5}{*}{2.01} & 7.48 & 5.47 & 3.72 & \multirow{5}{*}{3930} & 880 \\
\hline $\mathrm{Z8}$ & & & 7.18 & 5.17 & 3.57 & & 942 \\
\hline Z13 & & & 7.30 & 5.29 & 3.63 & & 845 \\
\hline S85 & & & 8.40 & 6.39 & 4.18 & & 575 \\
\hline S95 & & & 8.32 & 6.31 & 4.14 & & 694 \\
\hline
\end{tabular}


The highest increase in $\mathrm{pH}$ has been observed for Britton-Robinson buffer where the $\mathrm{pH}$ increased $3.57-4.18$ times compared to the initial one. Regarding the other leaching agents, the relative $\mathrm{pH}$ increase was found 1.20 - 1.34 and 1.34 - 1.42 times, respectively, for distilled and rain waters. The increase in $\mathrm{pH}$ values was caused by leaching the alkali compounds from the cement matrix and consequently surface precipitation of the new formed compounds as reported in [9]. When comparing the particular concrete samples, the highest $\mathrm{pH}$ changes were recorded in distilled and rain water for reference samples what points to the more intensive leaching of reference samples. On the contrary, slag-based concrete samples which were responsive for the lowest $\mathrm{pH}$ changes in water, have been found to cause the highest $\mathrm{pH}$ changes in Britton-Robinson buffer.

As it can be observed in Table 2, due to concretes leaching, the conductivities of both distilled water and rain water have been increased significantly. The raise of ions in both distilled and rain waters is linked with the leaching process or formation of compounds dissociated in the leachate. The decrease in conductivity of Britton-Robinson buffer was likely caused by neutralization reactions of alkali-based leaching products of concretes with acidic components of the Britton-Robinson buffer.

The measured hexavalent chromium concentrations in leaching agents after 300 days of the experiment are given in Table 3. The leachability of concrete samples in selected leaching agents was evaluated by the total leaching rate $V_{d}$; calculated for all samples by dividing the measured dissolved mass of chromium in a particular water-based leaching agent by the corresponding time of exposure ( 7200 hours) and total surface of the sample, as shown in equation (1) according to [8]:

$$
\mathrm{V}_{\mathrm{d}}=\mathrm{X}_{\mathrm{d}} /(\mathrm{T} \times \mathrm{S})
$$

where, $V_{d}=\mathrm{Cr}$ (VI) leaching rate per unit area $\left(\mu \mathrm{g} / \mathrm{h} \cdot \mathrm{m}^{2}\right) ; X_{d}=$ maximum amount of hexavalent chromium ions leached-out during the experiment $(\mu \mathrm{g}), T=$ period of test $[=24 \mathrm{x}$ days of leaching (hours)]; $S=$ area of exposure surface $\left(\mathrm{m}^{2}\right)$.

Table 3: Different levels of hexavalent chromium in leachates and leaching rates

\begin{tabular}{|c|c|c|c|}
\hline Sample & Leaching agent & $\begin{array}{l}\mathbf{c}\left(\mathrm{Cr}_{\mathrm{VI}}\right) \\
{[\mathrm{mg} / \mathrm{L}]}\end{array}$ & $\begin{array}{c}\mathrm{V}_{\mathrm{d}}\left(\mathrm{Cr}_{\mathrm{VI}}\right) \\
{\left[\mu \mathrm{g} \times \mathbf{1 0}^{-1} / \mathrm{h} . \mathrm{m}^{2}\right]}\end{array}$ \\
\hline \multirow{3}{*}{$\begin{array}{c}\mathrm{R} \\
\text { Portland cement }\end{array}$} & Distilled water & 0.033 & 2.91 \\
\hline & Rain water & 0.021 & 1.92 \\
\hline & Britton-Robinson buffer & 0.013 & 1.24 \\
\hline \multirow{3}{*}{$\begin{array}{c}\mathrm{Z} 8 \\
\text { Portland cement }+ \\
8 \% \text { of zeolite }\end{array}$} & Distilled water & 0.042 & 4.04 \\
\hline & Rain water & 0.043 & 4.55 \\
\hline & Britton-Robinson buffer & 0.008 & 0.82 \\
\hline \multirow{3}{*}{$\begin{array}{c}\mathrm{Z13} \\
\text { Portland cement }+ \\
13 \% \text { of zeolite } \\
\end{array}$} & Distilled water & 0.059 & 5.75 \\
\hline & Rain water & 0.055 & 5.29 \\
\hline & Britton-Robinson buffer & 0.017 & 1.66 \\
\hline \multirow{3}{*}{$\begin{array}{c}\text { S85 } \\
\text { Portland cement }+ \\
85 \% \text { of slag additive }\end{array}$} & Distilled water & 0.038 & 2.73 \\
\hline & Rain water & 0.030 & 2.77 \\
\hline & Britton-Robinson buffer & 0.009 & 0.53 \\
\hline \multirow{3}{*}{$\begin{array}{c}\text { S95 } \\
\text { Portland cement }+ \\
95 \% \text { of slag additive }\end{array}$} & Distilled water & 0.026 & 2.13 \\
\hline & Rain water & 0.022 & 1.84 \\
\hline & Britton-Robinson buffer & 0.006 & 0.45 \\
\hline
\end{tabular}


According to [10] the lower is original $\mathrm{pH}$ of medium the higher hexavalent chromium concentration should be detected. In spite of the lowest initial $\mathrm{pH}$ (2.01), the lowest concentrations of leached-out chromium ranging from 0.45 to $1.24 \mu \mathrm{g} \times 10^{-1} / \mathrm{h} . \mathrm{m}^{2}$ have been measured in Britton-Robinson buffer compared to other leaching agents. This phenomenon was probably caused by a high initial level of dissolved ions in Britton-Robinson buffer corresponding to the high initial conductivity which inhibited the possibility of heavy metal leaching $[11,12]$. Thus, the correlation between $\mathrm{pH}$ and leached-out concentrations was not confirmed. The leaching rates of chromium for samples exposed to distilled and rain waters have been found to be more than four times higher except for the reference sample.

The leaching performance of concrete samples of various compositions was compared by using the leached-out masses of chromium per $1 \mathrm{~kg}$ of binder (ppm), considering the differences in weights and dimensions of concrete samples, as it is seen in Figure 1.

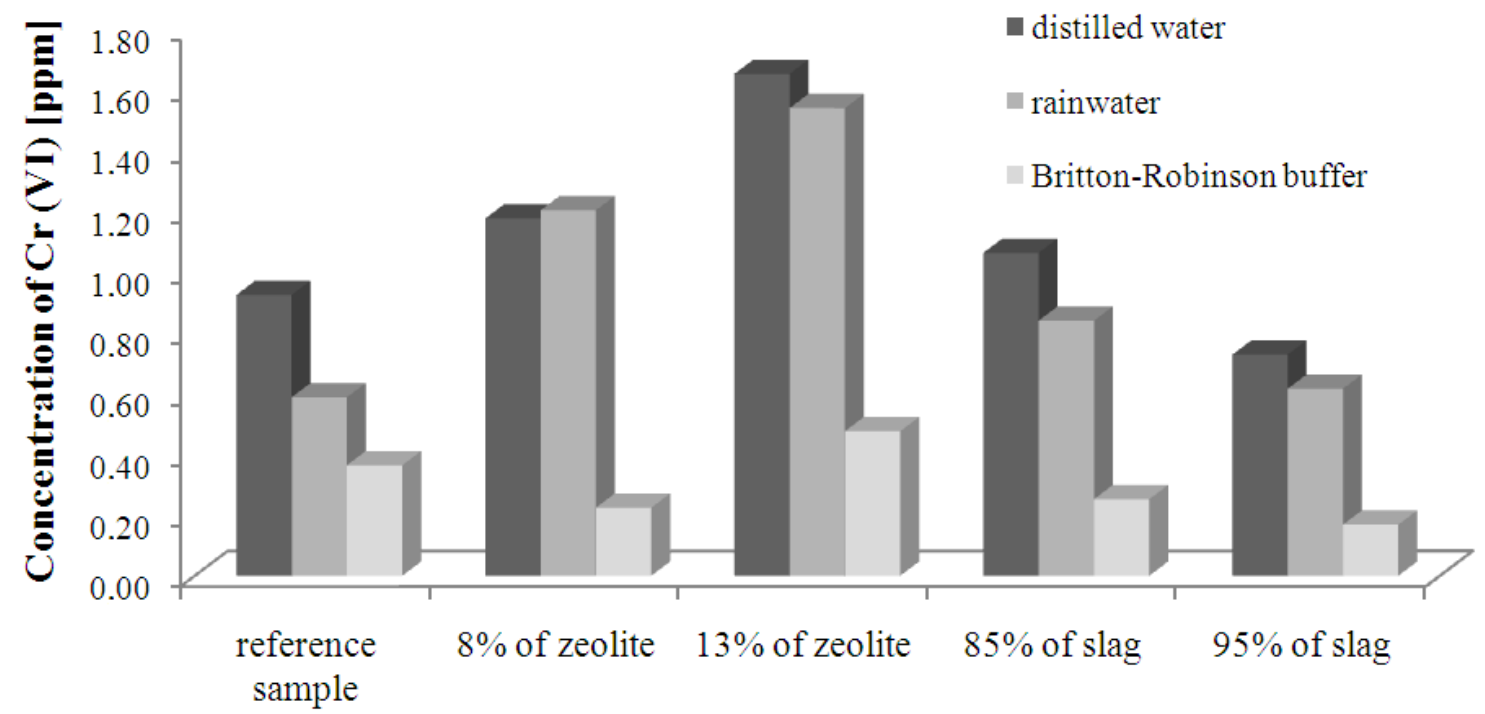

Figure 1: Leached-out masses of hexavalent chromium from the concretes of various compositions

When comparing the leached-out concentrations of hexavalent chromium regarding the concretes composition, it can be concluded that the samples with zeolite addition leached out more chromium than the reference composites and the concretes with slag addition, as well. In addition, the higher mass of leached-out hexavalent chromium was observed with increasing content of zeolite in samples. This trend was found out in each leaching agent: distilled water, rainwater and Britton-Robinson buffer, respectively. Analysing the leachedout chromium masses due to rainwater exposure, the concrete samples with both zeolites and slag additions proved the increased leachability compared to the reference sample. When considering the rain water as the most probable leaching agent in the environment, among the studied ones, the incorporation of the wastes into concretes could slightly rise a risk of the chromium leaching from the concrete materials. 


\section{Conclusion}

The incorporation of secondary raw materials and waste into building materials brings economic benefits, but on the other hand, there is a substantial risk of harmful emissions into the environment. In this experiment, it was found out that the most aggressive leaching agent is distilled water containing a very small amount of dissolved ions. The lowest aggressive leaching agent was found out the Britton-Robinson buffer, even with the very low $\mathrm{pH}$ value.

The content of hexavalent chromium ions in leachates of samples with zeolite was higher than in the leachates of samples with slag addition and reference samples without additive, respectively. In fact, the lower concentrations of hexavalent chromium ions were observed in Britton-Robinson buffer leachates (despite low $\mathrm{pH}$ value) due to high value of conductivity. Distilled water and rain water were more aggressive than Britton-Robinson buffer. Despite low $\mathrm{pH}$ value of Britton-Robinson buffer, the low level of leached hexavalent chromium was observed even lower than in water solutions.

\section{References}

[1] Baker P. G. \& Bishop P. L. (1997). Prediction of metal leaching rates from solidified/stabilized wastes using the shrinking unreacted core leaching procedure. Journal of Hazardous Materials.52, 311-333. DOI: 10.1016/S0304-3894(96)01814-6.

[2] Douglas E. \& Brandstetr J. (1990). A preliminary study on the alkali activation of ground granulated blast-furnace slag. Cement and Concrete Research. 20 (5), 746-756. DOI: 10.1016/0008-8846(90)90008-L.

[3] Salman M., Cizer Ö., Pontikes Y., Snellings R., Vandewalle L., Blanpain B. \& Balen K.V. (2015). Cementitious binders from activated stainless steel refining slag and the effect of alkali solutions. Journal of Hazardous Materials, 286 (9), 211-219. DOI: 10.1016/j.jhazmat.2014.12.046.

[4] Karakurt C. \& Topçu İ. B. (2012). Effect of blended cements with natural zeolite and industrial by-products on rebar corrosion and high temperature resistance of concrete.Construction and Building Materials. 35, 906-911. DOI: 10.1016/j.conbuildmat.2012.04.045.

[5] Najimi M., Sobhani J., Ahmadi B. \& Shekarchi M. (2012). An experimental study on durability properties of concrete containing zeolite as a highly reactive natural pozzolan. Construction and Building Materials.35, 1023-1033. DOI: 10.1016/j.conbuildmat.2012.04.038.

[6] Qasrawi H. (2014). The use of steel slag aggregate to enhance the mechanical properties of recycled aggregate concrete and retain the environment. Construction and Building Materials. 54, 298-304. DOI: 10.1016/j.conbuildmat.2013.12.063.

[7] Dokou Z., Karagiorgi V., Karatzas G. P., Nikolaidis N. P. \& Kalogerakis N. (2016). Large scale groundwater flow and hexavalent chromium transport modeling under current and future climatic conditions: the case of Asopos River Basin. Environ SciPollut Res Int. 23 (6), 53075321. DOI: 10.1007/s11356-015-5771-1.

[8] Ikeda M., Otsuki N., Nishida T. \& Minagawa H. (2004). Influence of Type of Cement on Ca Leaching from Concrete Using Experimental Acceleration Method. In 29th Conference on 
Our World in Concrete and Structures, August 25-26 (296-304), Singapore: CI-PREMIER PTE LTD.

[9] Kovalčíková M., Oravec J., Eštoková A. \& Luptáková A. (2016). Investigation of the precipitates on the concrete surface due to sulphate exposure. Selected Scientific Papers Journal of Civil Engineering. 11 (2).

[10] Komonweeraket K., Cetin B., Aydilek A.H., Benson C.H. \& Edil T.B. (2015). Effects of pH on the leaching mechanisms of elements from fly ash mixed soils. Fuel. 140, 788-802. DOI: 10.1016/j.fuel.2014.09.068.

[11] Gwenzi W. \& Mupatsi N.M. (2016). Evaluation of heavy metal leaching from coal ash-versus conventional concrete monoliths and debris. Waste Management. 49, 114-123. DOI: 10.1016/j.wasman.2015.12.029.

[12] Tiwari M.K., Bajpai S., Dewangan U.K. \& Tamrakar R.K. (2015). Suitability of leaching test methods for fly ash and slag: A review. Journal of Radiation Research and Applied Sciences. 8(4), 523-537. DOI: 10.1016/j.jrras.2015.06.003. 
